\title{
Anabel Torres. Una poética de la piel ${ }^{1}$
}

\author{
Anabel Torres. A Poetic from the Skin
}

\author{
Jennifer Natalia Mendoza Ariza \\ Universidad Industrial de Santander, Bucaramanga, Colombia \\ jemenari@correo.uis.edu.co|https://orcid.org/0000-0002-3862-341X
}

Recibido: 1 de octubre de 2019. Aprobado: 15 de junio de 2020

DOI: $10.25100 /$ lamanzanadeladiscordia.v15i1.8562

Artículo de reflexión

¿Cómo citar este artículo? / How to quote this article?

Mendoza, Jennifer. (2020). Anabel Torres. Una poética de la piel. La Manzana de la Discordia, 15(1), 209-234. doi: 10.25100/lamanzanadeladiscordia.v15i1.8562

\footnotetext{
${ }^{1}$ Artículo de reflexión, derivado de la intervención homónima realizada en la "Cátedra: Lectores y Lecturas" (Universidad de Antioquia, Colombia, el 13 de septiembre de 2019) y alimentada con las reflexiones surgidas en el marco del desarrollo de la investigación doctoral de la autora: Las representaciones del cuerpo femenino en la experiencia amorosa en Las bocas del amor y Agua herida, de Anabel Torres.
} 


\section{Resumen}

Este articulo parte de la inquietud que suscita la relación agónica entre filosofía y poesía, en la que la voz de las mujeres integra problemáticas diversas y centrales para los ámbitos del saber mencionados. Por ello, tomar como horizonte de estudio la obra Las bocas del amor, de la poeta colombiana Anabel Torres, posibilita la ocasión para pensar sobre: ¿Qué imágenes sobre la piel configuran la raíz poética de los versos contenidos en Las bocas del amor, de Anabel Torres? Para este fin, se recurre a los elementos provistos por la interpretación hermenéutica que, en un sentido amplio, proporciona las vías para abordar la experiencia de la lectura; emprender la comprensión de lo que puede entenderse por poema; aproximarse a la vida y obra de Anabel Torres al dar cuenta de las imágenes sobre el cuerpo y la piel. Todo esto condujo a una perspectiva en la que la piel está en el núcleo de la creación poéticofilosófica. En este sentido, el diálogo entre poetas y pensadores entre los que cabe mencionar a Chantal Maillard, Hélène Cixous, Jorge Luis Borges, Emilio Lledó, Jorge Larrosa y George Steiner allanan el camino para reconocer la fuerza tanto de la palabra femenina como la valía de las manifestaciones diversas de pensar y de crear.

Palabras clave: Cuerpo; piel; experiencia; escritura femenina; poesía; filosofía.

\section{Abstract}

This article is based on the concern raised in the tense relationship between philosophy and poetry, in which the voice of women integrates diverse and central problems in both fields. Therefore, in this approach the subject of interest was Las bocas del amor, by the Colombian poet Anabel Torres, because her work motivates think about: What images about the skin are in the poetic root of the verses contained in Las Bocas del Amor, by Anabel Torres?

Further, we used a hermeneutic interpretation for address the reading experience; study what can be understood by a poem; and analyze the poetic work of Anabel Torres when giving an account of the images on the body and the skin. All this led to a perspective in which the skin is at the core of poetic-philosophical creation. In this sense, the dialogue between poets and thinkers among which are Chantal Maillard, Hélène Cixous, Jorge Luis Borges, Emilio Lledó, Jorge Larrosa and George Steiner confer the approaches for recognize the strength of the feminine word and the value of the diverse manifestations of thought and creation.

Keywords: Body; Skin; Experience; Female Writing; Poetry; Philosophy. 


\section{Introducción}

La tensa pero fructífera relación entre Filosofía y Poesía permite pensar cuestiones surgidas de aquello que despierta la perplejidad de los seres humanos. En esta ocasión, la reflexión en torno a la poesía nos convoca a presenciar otras miradas sobre la vivencia humana en la que se emplea el lenguaje para cantar al amor, al contacto con el otro, a las cosas que tejen la cotidianidad compartida.

De modo que, pensamiento y lenguaje, filosofía y poesía, y reflexión y emoción son tomados como caminos para dar cuenta de las vicisitudes y perplejidades de una lectora que se ha movido a través de las fronteras porosas del discurso filosófico y del lenguaje poético.

Así, el propósito de esta conversación, caracterizada por la puesta en práctica de la autonomía y la autenticidad implicadas en el acto de la lectura, es provocar el reconocimiento de una dimensión estética enraizada en la perspectiva acerca del mundo y los vínculos tejidos gracias a la percepción de la piel en la poesía de la escritora colombiana Anabel Torres. A partir del interrogante: ¿Qué imágenes sobre la piel configuran la raíz poética de los versos contenidos en Las bocas del amor, de Anabel Torres?

Para ir develando coordenadas que nos permitan acceder a una respuesta tentativa a la pregunta acabada de plantear, se recurrirá a las ideas concebidas por pensadores y pensadoras que pueden ser puestos en diálogo con la voz de Anabel Torres; entre los que se encuentra Chantal Maillard, Jorge Luis Borges y Emilio Lledó, por mencionar algunos.

Cabe señalar que, en primer lugar, se abordó la experiencia de la lectura; segundo, se esbozó una respuesta a la pregunta ¿qué es un poema?; tercero, se avanzó en la aproximación a la vida y obra de Anabel Torres por medio de apuntes sobre su relación con el contexto de la literatura colombiana y sobre las imágenes al cuerpo y a la piel con las cuales elaborar una perspectiva sobre "una poética de la piel"; a modo de cierre, se ofreció una visión integradora donde la piel es concebida como un lugar para la creación, en este caso, poético-filosófica.

En este punto, es preciso destacar que la metodología empleada para acometer la propuesta responde, en líneas muy amplias, a las pautas dadas por la interpretación hermenéutica, puesto que permite entablar el diálogo entre el devenir histórico de las ideas y los efectos de conectar la emoción que afecta la mente y el cuerpo durante la experiencia de lectura reflexiva de un poema que sirve de ocasión para filosofar.

Al afirmar que el abordaje hermenéutico busca la comprensión, en este caso, del texto, se requiere la disposición para aplicarnos el texto cada vez que se actualiza la interpretación, 
asumiendo que este puede presentarse como distinto (Gadamer, 1977); por esta razón, esta perspectiva múltiple y dinámica conduce a una percepción polémica del texto en la que no se agotan las posibilidades del lenguaje que le configura, porque ha de pensarse como un proceso abierto continuamente (Lledó, 1992).

Ahora bien, el encuadre hermenéutico orienta de forma general la práctica de la lectura dispuesta para adelantar la reflexión que sigue en páginas subsiguientes; pero, es preciso mencionar que la teoría literaria feminista termina de afinar y encauzar el estudio del contenido, las figuras, la enunciación, la voz, entre otros aspectos que ponen en evidencia la "escritura femenina", conceptualizada en torno al reconocimiento de un ser humano que crea desde una experiencia de mundo diferente a la masculina y que abre un universo simbólico inédito, por haber sido dejado al margen del discurso autorizado, pero elaborado desde tiempos remotos (Penagos, 2007).

Por lo anterior, es importante admitir, junto con Vilma Penagos (2007), que las herramientas de las que se valen quienes investigan, en esta latitud del globo, provienen de los epicentros tradicionales de la cultura, las cuales se apropian para alcanzar los objetos de estudio, como sucede en el campo de las teorías feministas que convergen en este artículo que da cabida a una experiencia de lectura-escritura encarnada, situada, para advertir la voz de las mujeres que nacen a la escritura. Particularmente, el acercamiento metodológico avanzado por Toril Moi (2006) pone en evidencia la existencia de un modo de escribir específico que está más allá de la discusión esencialista, en favor de subrayar el carácter revolucionario que posibilita una transformación política y sexual con efectos en el potencial para trastocar el orden simbólico de la sociedad.

\section{La experiencia de la lectura: devenir lector (a)}

Antes de abordar el problema central de esta disertación, es preciso cuestionarse las implicaciones del acto de la lectura. Una de las preguntas que cabe formularse es: ¿qué aspectos intervienen en el proceso de llegar a ser lector(a)? Al respecto, la primera consideración se relaciona con el encuentro con el objeto libro y la experiencia que se desencadena, porque cuando se lleva a cabo la inmersión en el acto de la lectura somos transformados de modo tal que la percepción de nuestro universo se amplía; pues, las palabras invocan sonidos, olores, visiones y percepciones táctiles con las cuales se recrean vivencias en las que efectivamente hemos participado o aquellas que, a partir del relato, somos invitados a compartir con el autor(a). Así, en la intimidad entre libro y lector(a), se produce una expansión de las fronteras 
del mundo; además, tenemos la oportunidad de sumarnos a la colectividad de hombres y mujeres de distintas épocas, al hacer parte de ese acervo de recuerdos, sensaciones, pensamientos y emociones que están en la base del sentido de lo humano. Sobre este punto, Héctor Abad Faciolince (2003) indica que es preciso reconocer la gran capacidad transformadora de la lectura, por cuanto esta implica la confrontación entre nuestra singularidad y la multiplicidad de voces que invitan a expandir nuestra mente.

La lectura no se agota en la acción de decodificación y captación del significado llano de las palabras que componen un texto; por el contrario, leer implica pasar por diferentes estadios en los que el(la) lector(a) se involucra en su totalidad; de manera que, se requiere cierta complicidad y afinidad vital entre el libro y quien lee. Lo acabado de señalar concuerda con la propuesta de lectura desarrollada por Jorge Larrosa (1996) quien, en su obra La experiencia de la lectura. Estudios sobre literatura y formación, adelanta una reflexión sobre el acto de leer, las circunstancias que lo propician, sus efectos en el alma y el cuerpo del lector, entre otros aspectos, acudiendo a figuras icónicas de la filosofía y la historia como Platón y Nietzsche, por mencionar algunos.

En este planteamiento, la experiencia de leer da cuenta de la estrecha relación entre el sentido de la vida y la literatura, según se puede interpretar a partir de Larrosa (1996). De ahí que la literatura aparezca como un espacio propicio para tomar distancia, movernos hacia otras perspectivas, incluso, fugarse de la realidad por medio de otros lentes, bajo otra luz, empleando los recursos del lenguaje en los que la imaginación fluye sin dejar de mostrarnos la luminosidad y la oquedad del mundo.

Al advertir la capacidad reveladora de la lectura, es preciso notar que la piedra angular de dicha capacidad se encuentra en el manejo del lenguaje, tanto si la creación artística está dada en prosa o en verso; claro está la división básica expuesta aquí encierra en sí una discusión propia relacionada con los géneros literarios que podría resultar interesante en otro momento. Por el momento, la mención basta para señalar que quien se sumerge en la experiencia poética accede a otros matices y se tocan de modo particular las fibras respecto a quien participa del encuentro con la narrativa de las novelas o el ensayo.

Así, al detenernos en los efectos que el lenguaje poético produce sobre el alma, se puede hallar discursos célebres a favor y en contra de esa sabiduría contenida en el canto que, desde tiempos primigenios, ha prestado su voz a las inquietudes cruciales del ser humano situado frente a la naturaleza, a sus congéneres y a los dioses. Desde este ángulo, de acuerdo con Larrosa 
(1996): “Las palabras que pronuncian los poetas, las imágenes artísticas que fabrican los artesanos, el ritmo y la armonía de la música, penetran lenta e inconscientemente en el interior del alma y, sin que nos demos cuenta, la conforman" (p. 70).

En efecto, el impacto que causa la poesía en el alma mueve las pasiones y lleva al intelecto hacia terrenos donde lo posible está siempre en capacidad de aparecer; en otros términos, la poesía nos lleva a considerar el flujo constante del cosmos, entendiendo que la multiplicidad, la renovación y los ciclos son parte fundamental de nuestra presencia en este tiempo y espacio.

En medio de esas posibilidades engendradas por el lenguaje poético, permanece el carácter emancipador de la lectura, por cuanto nos permite posicionarnos siempre desde otras aristas, contemplar y desear ponernos en la piel del otro. Este rasgo se puede denominar "emancipador" por cuanto lleva a quien ejerce de lector(a) a un estado de cuestionamiento y ruptura en el que cabe revisar las condiciones bajo las cuales se cifran sus condiciones de vida, tal como puede acontecer con las mujeres, quienes a través del curso de la historia han librado diferentes luchas por el reconocimiento y en estos procesos socio-históricos el libro les ha servido de talismán, si se piensa en que leer y acceder a los libros fue tomado por ellas (las mujeres que nos antecedieron e incluso hoy) como una primera forma de independencia, pues, en el encuentro con el libro, ellas están cara a cara lectora-escritor(a) cuando pasan las páginas. Allí, en ese espacio de la lectura acontece una suerte de fuga de las coacciones y las exigencias sociales y familiares y un largo etcétera, para dar paso al vuelo de la sensibilidad y la mente en el que tiene lugar la grandeza de pensar por sí mismas y sentir libremente al amparo de la privacidad procurada al leer. Al respecto, se acude al testimonio como el contenido en el prólogo escrito por Lola Larumbe (2015) para el libro de Steffan Bollmann, titulado Las mujeres y los libros. Una pasión con consecuencias.

Ahora, conforme hemos planteado, el acto de leer comporta una serie de cualidades que permiten la expansión, la revelación, la emancipación y la libertad. Sin embargo, resulta necesario indicar que el lenguaje, recurso sin el cual seguramente no ocurriría la experiencia de la lectura, "solidifica de cierta manera las experiencias humanas, pero son éstas las que crean, orientan y determinan al lenguaje”, de acuerdo con Emilio Lledó (1970, p.11). A la luz de Lledó, se advierte que esa capacidad del lenguaje para contener, de alguna manera, las experiencias humanas pueden convertirse en arma de doble filo, pues está presente el riesgo de petrificarse y asfixiar el centro y motor de las vivencias. Este peligro enunciado nos lleva a pensar en aquello que los filósofos han denominado como los "límites" del lenguaje. 
Al detenernos en la cuestión acerca de si el lenguaje tendrá límites, resulta válido atender a George Steiner (2003), quien plantea:

Hay modalidades de la realidad intelectual y sensual que no se fundamentan en el lenguaje, sino en otras fuerzas comunicativas, como la imagen o la nota musical. Y hay acciones del espíritu enraizadas en el silencio. Es difícil hablar de éstas, pues ¿cómo puede el habla transmitir con justicia la forma y vitalidad del silencio? (p. 29).

Conforme argumenta el filósofo y ensayista citado, las fuerzas intrínsecas de lo que acontece a nivel intelectual y sensual pueden expresarse de otras formas, tales como la música, las imágenes, el silencio. Por ello, nos atrevemos a incluir el gesto, el icono, los bits, entre otros medios alternativos al lenguaje codificado, pensando que los espacios en los que tiene lugar la comunicación han adquirido nuevos matices, debido a nuestra realidad entreverada con la virtualidad. De esta forma, el lenguaje y la expresión dinamizan los bordes planteados por la palabra hecha código, para dar lugar a comunicarse a través de otros medios como la poesía, entre otras formas de expresión.

Además, cabe señalar que la pregunta incluida en la alusión al pensador francoestadounidense: “¿cómo puede el habla transmitir con justicia la forma y vitalidad del silencio?", podría reformularse cambiando la palabra habla por lenguaje y desde allí indagar no solo por los límites del mismo, sino acerca de las posibilidades que se incorporan al silencio y a otras formas de expresión, donde la presencia de lo inefable (lo indecible, aquello que no puede explicarse con palabras) no conduzca irremediablemente al horror vacui.

Hasta este punto, hemos observado aquellos aspectos que intervienen para que el acto de la lectura ocurra, así como se ha sostenido que dicho ejercicio conduce de modo inexorable a quien se encuentra con el libro a cierta condición en la que se deviene lector(a), entendiendo el devenir como ese proceso en el que algo llega a ser. En este caso, se deviene lector(a), en principio, por la invitación de unas páginas encuadernadas; luego, las circunstancias propicias para la lectura pueden aparecer y las disposiciones anímicas e intelectuales pueden ser estimuladas en diversos grados; de suerte que, en medio de la soledad y el silencio, opera la capacidad de emancipar y transformarse adquirida por el ejercicio de libertad inherente a la lectura. En ese devenir lector (a) la experiencia de leer poesía presenta una serie de potencias bajo las cuales el alma (el sentido interno, la psiquis, las fibras) es permeada de tal forma que después no somos los mismos, quizá porque hemos adquirido la sabiduría de la metamorfosis, 
de lo múltiple, de lo particular, de lo íntimo; aspectos que permanecían fuera de los muros de la ciudad soñada por ese pensamiento que discurre y que ha llevado por lustros a la filosofía y a la ciencia a establecer sus edificios conceptuales.

\section{Hacia una comprensión del poema}

Ahora bien, si devenir lectores es una experiencia que nos cambia profundamente, acercarse al lenguaje poético comporta otra dimensión en la que la relación entre libro y lector(a) tiene lugar bajo diferentes connotaciones. Por esta razón, es preciso preguntarse por el poema.

Al respecto, se podría acudir a diversos teóricos literarios, filósofos y poetas, pero la discusión nos tomaría un largo tiempo. No obstante, aquí se propone un abordaje en el que se representa la cercanía entre la filosofía y la poesía al recurrir a algunas ideas desarrolladas por un poeta-filósofo, Jorge Luis Borges, y a una filósofa-poeta, Chantal Maillard, a partir de quienes se reconstruye algunos apuntes para figurarnos qué se puede entender por poema.

En primera instancia, se acude a la visión de Borges (2001) sobre la poesía, lograda con la lectura de Arte poética, título en el que se adelanta una disertación sobre la poesía, el poema y sus recursos. En la obra citada, aparece la asociación entre poema y experiencia, según las siguientes líneas: “Así, podría decirse que la poesía es, cada vez, una experiencia nueva. Cada vez que leo un poema, la experiencia sucede. Y eso es la poesía” (p. 21).

Pero, ¿qué vínculo tienen la poesía, el poema, el lenguaje y el mundo? ¿En qué medida el ser humano se sumerge en la experiencia de la poesía? Al respecto, el escritor argentino deja trazas desde las cuales es posible revisitar su punto de vista, por ejemplo, distingue entre quienes acceden a la poesía teniéndola como objeto de estudio y quienes realizan una inmersión desde la pasión y el placer (Borges, 2001). Esto desplaza el foco de atención de la estética (teoría) hacía la autenticidad de la poesía.

Una vez se ha subrayado el cambio de punto focal, se advierte una forma particular de asumir la definición de la poesía; puesto que, el escritor admite una suerte de definición provisional, en la cual la poesía y el lenguaje son tomados como expresión (Borges, 2001). Lo anterior es trascendido para dirigir la mirada a la vida que es la fuente de la poesía, es decir, la vida es ese lugar-espacio en el cual podemos hallarla de súbito.

Alrededor de la concepción en la que poesía y experiencia están íntimamente ligadas, de acuerdo con Borges, la conexión entre el poema y la experiencia de estar en su presencia se torna en constante para el acontecimiento de lo poético y sus efectos en el alma. La emoción que despierta en quien lee o escucha poesía se vincula con los acontecimientos circundantes. 
Por ello, el lenguaje poético no es únicamente medio para la comunicación, sino también para la "pasión y el placer" (Borges, 2001, p. 20); pues el grado de afección va más allá del significado de las palabras, dado que el cuerpo, las emociones y la inteligencia son necesarias en la experiencia suscitada por la poesía.

De pronto, cuando ya se ha aceptado que la auténtica experiencia poética radica en la inmediatez de su afección, Borges, retoma el asunto de dar con una definición de poesía, apoyada en Croce (citado en Borges, 2001) quien permite abordar el problema de la definición de la poesía en los siguientes términos:

Por ejemplo, si tengo que definir la poesía y no las tengo todas conmigo, si no me siento demasiado seguro, digo algo como $<<$ poesía es la expresión de la belleza por medio de las palabras $>>$. Esta definición podría valer para un diccionario o para un libro de texto, pero a nosotros nos parece poco convincente. Hay algo más importante: algo que nos animaría no sólo a seguir ensayando la poesía, sino a disfrutarla y a sentir que lo sabemos todo sobre ella (p. 34).

Sin embargo, se insiste en la existencia de una fuerza que impulsa a seguir ensayando y a disfrutar la poesía; la idea anterior, enfatiza en que se puede dar una definición como ejemplo, pero en el núcleo persiste la potencia de la poesía que permea más allá del lenguaje, de la expresión, de la reflexión, con el objeto de asistir a la inmediatez de su capacidad de afectación.

Ahora, al reevaluar la fuente y la posibilidad de definir la poesía, el poeta empuja los límites de la definición objetiva de poesía, cuando se establece que el conocimiento de la misma tiene lugar en ese encuentro con el poema, en el que la vivencia se arraiga de modo tal que no se precisan palabras adicionales más que "esos símbolos comunes que compartimos" (Borges, 2001, p. 34), para dar cuenta de esa experiencia inmediata: "ese especial estremecimiento" (p. 35), heredado colectivamente para la humanidad.

Como se puede observar en las palabras reproducidas, el vínculo entre poema y experiencia se caracteriza por una conexión bilateral en la que los términos implicados aparecen como catalizador del otro. Esta dinámica ilustra la forma en que el ser humano manifiesta su estar en el mundo, al admitir, por un lado, una concepción del poema en la que su fuente originaria se halla en las cosas y los acontecimientos; y por otro, se reivindica la potencia del poema para llevar a su lector(a) a una inmersión vívida de situaciones, recuerdos y emociones que pueden no haberle sucedido, pero con las que se identifica. 
En segundo lugar, la filósofa y poeta española, nacida en Bélgica, Chantal Maillard (2014), en su obra La baba del caracol, lleva a cabo una indagación crítica sobre los puntos fundantes de la discusión sobre el arte en la que la relación entre la poesía y la filosofía tiene un rol relevante. Al avanzar en la lectura de su propuesta reflexiva, incluso el estilo con el que escribe y presenta las ideas, lleva a quien intenta seguirla a crear y a atreverse a pensar, así como a sentir desde lugares insospechados en el universo del ensayo. Este aspecto de su obra atrae y reta al/a la lector(a) del mundo contemporáneo, quien se ve obligado/a a detener la prisa para respirar, al modo del Pranayama de las prácticas espirituales de Oriente.

Una vez se asume el desafío de la lectura, los interrogantes expuestos en la obra son desarrollados al emplear diversos recursos, donde la metáfora y las imágenes proveen esclarecimiento. Así, una de las cuestiones tiene que ver con la obra de arte. Al respecto, Chantal pregunta: “¿Es el poema una obra de arte?” (Maillard, 2014, p. 11) y responde a través del "como si", lugar para la semejanza y de ese modo introduce la idea de que: "Un poema es una obra, algo que se presenta y se dice, y lo que dice no es distinto de la forma en que se dice" (Maillard, 2014, p. 12). Aquí, se afirma que forma y contenido guardan la misma importancia en el arte poético; a su vez, conduce a pensar que la metáfora representa ese modo por medio del cual el material tomado de la realidad, fuente de la poesía, es transformado por la imaginación al punto de impedir la separación de la imagen lograda y su sentido.

En otro pasaje, aparece la siguiente denominación: "Llamo poema a aquello mismo que enseña (qui apprend) el corazón, a aquello que inventa el corazón” (Maillard, 2014, p. 16). Con esta afirmación, el poema puede pensarse como experiencia en una dimensión lúdica, si se quiere, donde hay lugar para estar expuesto a aquello que el corazón pueda aportarle al ser humano, más allá, de lo que se ha aprendido desde la lógica y la comprensión de la razón privilegiada en Occidente.

Pero, inmediatamente, nos preguntamos: ¿cómo sería posible aprender del corazón? Pues bien, esto es viable dada la capacidad del poema de hacer del lenguaje su casa, para tomar las palabras y traerlas a la vida. Así, el lenguaje está en capacidad de vehicular vivencias, sentimientos y saberes, por cuanto los usos a los que se presta la palabra alcanzan el nivel del símbolo (Maillard, 2014, pp.18-19). La metáfora para hacernos comprender la relación entre el poema y el lenguaje, acudiendo a algo más que el concepto y los significados de las palabras, es el cangrejo que usa las conchas. Como se reproduce en seguida: 
El poema utiliza las palabras como el cangrejo las conchas; como él, se retuerce para adaptarse a las volutas de su hábitat. Lo que vemos del poema es lo que vemos del ermitaño: su concha, una envoltura prestada, con la que muchos le confunden. Muchos incluso lo recogerán porque les llama la atención su hermosa apariencia, sin sospechar siquiera que alberga un ermitaño (Maillard, 2014, p. 19).

En el fragmento citado, la imagen del cangrejo ermitaño brinda eso que se había presentado como sabiduría del corazón, eso que está en el puro contacto con la naturaleza y sus manifestaciones y que, durante el transcurrir de los tiempos, se ha desdibujado por acción de una tradición que convirtió la mediación de la palabra y el concepto en una Torre de Babel desde la cual es difícil adquirir la experiencia.

De ahí, el poema se presenta como otra vía de sabiduría perdida o poco reconocida, desdibujada seguramente por el paso del tiempo. También, se percibe que el poema entraña una fuerza vital, apoyada en la singularidad que da paso al continuo estar-siendo de las cosas; además, se encuentra inmerso en una especie de infinitud continua que no es abarcable por la razón. Al aparecer como inabarcable, en Chantal Maillard (2014) se lee la descripción del advenimiento del vértigo y la náusea en respuesta a la pérdida de la definición de las cosas, en ausencia de las delimitaciones elaboradas por el mí, presentado como una de las formas del hombre racional que se posesiona y delimita cuanto existe haciendo uso del acto de nombrar.

En esa visión del efecto somático del mí se nota una crítica a los parámetros bajo los cuales se ha acumulado el conocimiento en Occidente. Contrario al extravío y al malestar sufrido por el mí, se evidencia otra forma de volver a respirar, con otro ritmo, al tomar conciencia de cada uno de los momentos de la respiración: inhalar-sostener-exhalar. En palabras de la filósofa española:

La inspiración forma parte de la respiración. Nuestra respiración. Nuestro ritmo. Pero también el de aquéllos que tenemos a nuestro lado. El ritmo de los otros, el de las cosas-siendo. El de una pared, por ejemplo, el de una piedra...Entre todos, sucedemos (Maillard, 2014, p. $40)$.

En medio de este otro ritmo, el nosotros acoge y transforma al mí. El nosotros otorga al mí un nuevo contacto con los otros, con las cosas, consigo mismo, lo cual deriva en adquirir 
otro tipo de atención más orgánico y natural, sincronizado con los ritmos de la naturaleza, si se quiere (Maillard, 2014).

De lo expuesto anteriormente, es posible percatarnos de qué maneras el lenguaje poético transmuta la experiencia de la lectura. Para ahondar en este aspecto, cabe resaltar las siguientes líneas:

El que lee filosofía, decía, levanta a menudo la cabeza como hace un pájaro al beber; así lo leído se filtra, como el agua en la garganta del pájaro, y se asienta en el entendimiento. Y, en efecto, yo había estado realizando, durante mi lectura, aquel mismo gesto del pájaro: levantar la cabeza, entrecerrar los ojos y volver al agua. Sólo que, esta vez, no estaba leyendo precisamente un ensayo, sino un libro de poesía. Me di cuenta entonces de que la misma necesidad había, en ambos casos, de dejar que el agua se filtrase y hallase su camino hacia el núcleo. Y allí tenía lugar una comprensión (Maillard, 2014, p. 47).

En las palabras recuperadas, cabe resaltar la imagen del pájaro en el árbol que bebe agua; porque nos enseña cómo realizar la lectura tanto de filosofía como de poesía. Pues bien: al leer ocurren una serie de movimientos y efectos físicos, mentales y emocionales para procurar la comprensión. En simultáneo, acontece la afección del tiempo, pues la descripción misma conlleva una temporalidad sosegada en la cual se permite que lo leído "encuentre su camino" y se "asiente".

Entonces, la caracterización del poema exhibe un cambio. De acuerdo con la siguiente cita: "Poema: aprehensión de lo-que-hay en un modo. Infringiendo los límites" (Maillard, 2014, p. 49), se advierte: uno, no hay presencia del verbo copulativo "ser", lo cual es un indicio de que no se trata de una definición tradicional de poema; dos, el primer verbo aprehensión aparece sustantivado, con lo cual puede señalarse la fase resultante de un proceso; tres, de, preposición, generalmente denota pertenencia; cuatro, lo-que-hay, expresión que alude no al ser sino a cuanto existe, es decir, más allá de la mención exclusiva ontológica del ser, por cuanto incorpora las acepciones del haber y del existir; cinco, en un modo, expresión formada por una preposición en que denota lugar, tiempo, modo, junto a un adjetivo que indica cantidad (un) y un sustantivo (modo), con estos tres componentes afianza la idea de la existencia de la proliferación de modos en los que el poema puede manifestarse. Acto seguido, incluye la expresión formada por un verbo conjugado de modo no personal en un tiempo continuo infinito (infringiendo), junto a un 
complemento (los límites) que enfatiza la transgresión a las reglas silogísticas que han regido la expresión de lo que "son" las cosas.

En este sentido, cuando se lee a Chantal Maillard (2014), cobra preponderancia el modo en el que tiene lugar esa aprehensión (entendida como la comprensión de algo prescindiendo de juicio alguno, es decir, de forma inmediata) cuando emplea la imagen del poema-pájaro; pues, dicha imagen lleva atada la necesidad de adicionar el rasgo preeminentemente musical que adquiere el modo en que la metáfora y el poema operan como canales de acceso a la experiencia.

Otro rasgo, además de la musicalidad y la potencia de ruptura, el poema tiene que ver con cierta disposición espacial en la que aparece dispuesto horizontalmente, cuya concepción de horizonte se acerca al juego y al paisaje compuesto del bosque, donde la perspectiva que potencialmente demarcará estará dada por la fluctuación de los componentes de la imagen. También, cabe mencionar que no se excluye del todo la verticalidad, pues es una opción más del movimiento acogida por la fluctuación que al hacerse vertical se aproximaría a la filosofía (Maillard, 2014), de manera que la filosofía se recibiría en la expansión del poema.

En síntesis, preguntarse por el arte, el poema, sus recursos y los alcances de la palabra poética conduce a separarse de los esencialismos, con el fin de apreciar los elementos en la relación poesía-filosofía desde una sensibilidad despierta que permite reivindicar el conocimiento logrado en la raíz de la experiencia: el vínculo del ser humano con la naturaleza. Así, el poema se convierte en lugar que acoge la fuerza de la vivencia humana, para acceder a un todo que es dinámico y que acontece cuando la vida transcurre, lo cual se aprende con el corazón, según se vislumbra al reflexionar sobre las propuestas de Borges y Maillard.

\section{Ir al encuentro con la poesía}

Después de haber esbozado las perspectivas comprensivas acerca de la experiencia de la lectura y del poema, es momento de introducir a la poeta y su obra, motivación de estas páginas. Para este fin, se ha optado por traer ciertos pasajes en los que ella misma da cuenta de sí y de su papel de mujer escritora.

Para acercarnos a una obra y a su creadora, como punto de partida vale mencionar que Anabel, nacida en Bogotá, traza su línea biográfica posicionada a través de su propia narración. Como se observa a continuación: 
Mi crianza fue distinta en algunos aspectos. Nací en Bogotá el 28 de diciembre de 1948, concebida semanas antes de que asesinaran a Jorge Eliecer Gaitán aquel 9 de abril de 1948, y se desatara 'La Violencia' ya sin frenos. Cuando yo nací, afuera rugía la guerra y en mi casa había amor. Al comenzar el régimen militar del General Rojas en 1953, a Eddy, mi padre, Director hasta esa fecha de la revista Semana, le exigieron sacar la foto de un militar en la portada y él renunció. La familia empacó sus bártulos y sus cuadros y nos fuimos a Medellín, donde Eddy se dedicó a la publicidad mientras pasaba la dictadura (aquella fue su época más solvente) (Torres, 2015, s.p.).

En ese pasaje se asiste al testimonio de una mujer concebida y venida al mundo en una violencia que ha enmarcado a muchas generaciones de colombianos/as que contrasta con el amor que se procura por fuerza, quizá de la esperanza, al interior de los hogares. Habla del padre, Eddy, periodista, obligado a dejar su lugar de trabajo y su modo de vida, quien inauguró el trasegar de la familia por ciudades y países, tal como sería luego la forma de vida asumida por Anabel. Es así como, una vez asentada la familia en Medellín, la niña es educada en casa, en razón a que, conforme ella manifiesta en apartes de su ensayo biográfico, para la época los niños de familias burguesas no asistían a la escuela pública y su padre no quería inscribirla en colegios de monjas.

Asimismo, en Medellín, las vivencias con los abuelos Nacho y María (Ignacio Giraldo y María Cano, destacados líderes sindicales colombianos) se fijan en la memoria gracias a los relatos del abuelo, en los cuales la brecha entre personaje y relato acentúa las contradicciones propias de la violencia generalizada en Colombia. Obsérvese en seguida:

En la terraza criaban palomas y pensamientos. Yo de niña iba a visitarlos y pasaba horas dibujando en el escritorio de Nacho. Él me narraba historias, mientras me instaba a diseñar y practicar mi 'firma'. A veces me contaba sobre sus entradas y salidas a la cárcel, acompañado de mi padre de tres o cuatro años. Como no podía imaginarme que él o María fueran unos bandidos, yo pensaba que ir a la cárcel o tener balas bailando por encima de la cabeza era simplemente algo que podía pasarle a la gente cuando era grande (Torres, 2015, s.p.). 
Dos circunstancias que marcaron la vida de la poeta, se pueden sintetizar así: una, la muerte de uno de sus hermanos, debido a la meningitis; dos, el traslado de la familia a Nueva York, a la edad de 8 años, cuando el país pasaba de una dictadura al establecimiento de una junta militar, movidos por lo que ella denomina "morir de Colombia", al referirse a las muertes por balas perdidas o en circunstancias ajenas a la participación directa en el conflicto armado.

Al revisar los extractos compartidos, hasta ahora, se ha posibilitado un encuentro con la infancia y los recuerdos familiares de una mujer que escribe poesía, palabrera como ha optado por llamarse y quien se posiciona frente al mundo literario contemporáneo de una forma significativa para ella, según se advierte en los siguientes fragmentos recuperados:

Soy entonces una nadie representativa, como tantos. (...)

Frente a la realidad contemporánea, me coloco como ser sintiente y pensante y hasta la palabra poeta sería reduccionista. Prefiero no dejarme atrapar en definiciones, ni siquiera en mi túnica preferida de poeta. La realidad que vivimos desafía toda definición (Agustoni, 2003, s.p.).

En lo expresado anteriormente, se aprecia la sensibilidad por el mundo en el que vive y escribe, sin mostrarse ajena; por el contrario, parece vinculada y reflexiva respecto al mundo que la circunda.

Ahora, si bien la autora se presenta empleando sus coordenadas particulares (la familia y los recuerdos de la infancia), no escapa a la reflexión sobre su posición respecto al contexto socio-político de la época; pues, se piensa de modo relacional, es decir, indicando formas en que el acontecer local y mundial puede incidir en cómo se ve a sí misma y en su creación. En este orden de ideas, quien la entrevista le pregunta: “¿Y qué mujer eres tú frente a tu destino?” (Agustoni, 2003, s.p.). A esto Anabel responde:

Soy una mujer femenina y feminista, por lo tanto femininista; sola y acompañada, porque mis amigos y amigas me quieren, y mi hija y mi hijo, y mis dos nietas y un nieto; una mujer que sigue soñando despierta con el amor con más ahínco que nunca, a medida que más lejano lo percibe, porque el amor es aquel 'espacio en el medio' por excelencia, esa dimensión donde lo cotidiano más nimio cobra magia y el sentido primigenio de creación (Torres, en Agustoni, 2003, s.p.). 
Al revisar las afirmaciones transcritas, su postura da cuenta del anclaje existencial dado por los afectos, sin perder de vista su compromiso político. Se subraya la confluencia del entorno íntimo y el externo, en razón a que aparece acogiendo las dimensiones en las que su existencia se mueve: los vínculos, su ser como mujer, asumiéndose feminista, creadora. Todo esto tiene lugar en ese espacio con el que figura el amor.

Al llegar a este punto, vale la pena preguntarse por sus consideraciones acerca de lo que atañe a la creación poética. Sobre este asunto, en el ensayo publicado en 2015, expone su creencia acerca de la existencia de una ventaja al escribir poesía siendo mujer, dado que pueden permitirse un grado de libertad descubierto en medio de la exclusión o el atenuado reconocimiento de la escritura de las mujeres; situación observada de forma directa en la literatura colombiana. Esa libertad ha otorgado a las escritoras la capacidad de seguir escribiendo sin tener la etiqueta de "escritor colombiano" o de "intelectual", lo cual conduce a experimentar y trabajar en sus creaciones en condición de "principiantes", esto es, buscando resolver sus dudas a la luz de la labor de escribir, tachar, revisar, enfrentar las dudas, discutirlas, buscar consejo.

Otra mirada a las ventajas o desventajas de la escritura desde el ángulo femenino, se encuentra en la entrevista concedida en 2003, donde rescata el hecho de que las mujeres poseen una manera distinta de abordar el mundo que se trasluce en la forma en que se encara la página en blanco; sin embargo, esta diferencia es catalogada como importante sin llegar a ser crucial, en razón a las posibilidades de la palabra que parecen trascender el género. Por ello, el género puede tomar otras connotaciones y niveles de relevancia que se cruzan con la escritura, en la cotidianidad, en las relaciones con los demás, en la esfera política, entre otros ámbitos en los que situarse respecto a los demás y al mundo resulte primordial.

Luego de llevar a cabo este primer acercamiento al contexto que marcó la vida de la "palabrera" colombiana, está abierto el camino para traer perspectivas plurales sobre su vida y obra. En relación a esto, uno de los rasgos que destacan estudiosos de la Literatura colombiana, tiene que ver con las manifestaciones de las oposiciones vitales, de acuerdo a lo señalado en el siguiente pasaje:

Acercando lo particular y lo general, lo personal y lo político, esta poeta nos permite ver la extraña relación entre (oikos, la casa) y lo público (polis, la plaza), como dijera Habermas. Así conecta con una expresión 
que da a su voz un verdadero poder de verbo creador y actual (Parra, 2018, p. 9).

En las palabras recuperadas, sobresale el grupo de opuestos, sobre todo aquella pareja, históricamente prominente, compuesta por lo personal y lo público; porque, de inmediato surgen asociaciones entre el dominio de lo privado, lo cotidiano, lo hogareño frente a lo público, el afuera y lo político. No obstante, más allá de advertir la peculiaridad de la relación entre las dos dimensiones expuestas, representadas bajo diversos signos, cabe mencionar que la tensión puesta entre el orden de la casa y el orden de la plaza está cargada simbólicamente con tópicos que alientan la discusión de la ruptura ocasionada por las mujeres que, al hacer uso de la palabra, se rebelan contra el estado de cosas imperante.

Además de hacer énfasis en la rebeldía como vía exclusiva para transgredir, es preciso notar que ese carácter sesudo en que las mujeres buscan, planean y adoptan modos efectivos para llegar a la palabra, hacer uso de ella, abre el camino para legitimarse como seres existentes y valiosos, no solo ontológicamente, sino para efectos de la vida "pública-política". Sumado a esto, las experiencias surgidas del "nomadismo"2 local y lingüístico presente en los reportes sobre la vida familiar de Anabel y percibidos a través de su creación poética, harán parte del telón de fondo en el que la libertad, la ruptura, la ausencia de convencionalismos y el factor crítico, incluso contestatario, impregnará constantemente la voz de la palabrera colombiana.

Adviértase que el rasgo subrayado en la obra poética de Anabel, se circunscribe a un contexto en el que las voces femeninas comienzan a tener mayor presencia a medida que transcurre la década de 1970, conforme se señala en Sierra (2012). De modo que, al leer se está ante una voz que, de forma generalizada, ha sido tomada como referente para expresarse frente al "estado de cosas que le incomodan del mundo tal como está hecho" (p. 751). Así mismo, más allá de manifestar la posible desazón que puede provocar el destino en el que se cifra su existencia, la autora desarrolla un estilo en el que la ironía y el humor son recursos para mostrar de forma sensible la denuncia ante las desgracias de una cultura (Sierra, 2012). Denuncias también evidenciables en las faltas, las violencias y las dolosas incoherencias sobre las que se construyen los bastiones de la civilización humana.

Otro rasgo coexistente que marca la percepción de la poesía escrita por Anabel Torres es la fuerza vital presente en sus versos, la sensación de libertad dada por esa voz capaz de

\footnotetext{
${ }^{2}$ Los términos "nómada" y "nomadismo" son objeto de tratamiento por parte de filósofas feministas en sus propuestas teóricas, por ejemplo: Rosi Braidotti (2000). Aquí se incluye una visión conceptual y lingüística más cercana a las experiencias vitales de la autora que ha motivado estas páginas, según reporta Jaime Parra (2018).
} 
"[conversar] sin complejos y en un lenguaje muy propio, con la gran poesía de todos los tiempos" (Mendinueta, 2018, p. 15). De acuerdo con Lauren Mendinueta (2018), la poesía de Anabel "prefiere hurgar en lo hondo de la condición humana, denunciar los estragos de la crueldad en el mundo, (...) incomodar al lector con preguntas agudas” (pp. 16-17); lo cual lleva a percatarse de que el encuentro con su poesía, seguramente nos transformará.

Luego de haber conseguido una aproximación a la autora y a ciertos puntos sobre la percepción de su obra, es momento de acometer el ejercicio de lectura filosófico-poética, en torno a las imágenes del cuerpo y la piel presentes en Las bocas del amor. Aquí vale la pena indicar que el poemario Las bocas del amor vio la luz en el año 1982, bajo el sello editorial “árbol de papel” en cabeza de la autora. El libro está compuesto por 34 poemas y forma parte de un corpus con otros títulos, entre ellos: Casi poesía (1975); La mujer del esquimal (1981); Poemas (1987); Medias Nonas (1992); Poemas de la guerra (2000); En un abrir y cerrar de hojas (2001); Wonded Water/Agua herida (2004); Human Wrongs (2010).

El poemario en cuestión, titulado Las bocas del amor, se inaugura con un primer poema homónimo, en el cual la soledad impacta al cuerpo de una mujer que parece que su capacidad de contener y nutrir queda sin ser reclamada. Como se lee en los siguientes versos: "Cuando estoy sola como ahora/ la piel adquiere /un tono amarillento, /como de libro sin usar: //calostro /derramado" (Torres, 1982, p. 9). Los síntomas de la soledad se observan en el color mórbido de la piel, cuyo sentido se expande al incorporar el simbolismo del libro y del alimento materno, ambos desaprovechados.

En "Hacer cabriolas", el cuerpo aparece como territorio, país regido por reglas distintas a los anhelos del alma. Según se ilustra en seguida: “Aquí! /donde soy un país/ regido por las leyes del dolor y el asombro/ los pleonasmos del alma/ repitiendo/ amor, amor / desde las cataratas del cuerpo" (Torres, 1982, p. 13). En los versos extraídos sobresale la imagen del cuerpo como algo que brota y fluye en virtud del insistente pedido del alma en el que se conjura al amor, así como se observa la superación del estatus físico del cuerpo y aparece en forma líquida, dinámica, maleable y en capacidad de transformarse.

Desde este ángulo, el amor se torna en una constante que corre en paralelo a las transformaciones y afecciones del cuerpo. En efecto, esta es una visión activa, dinámica de una visión de mujer que encarna una réplica al rol adjudicado históricamente a lo femenino. Alrededor de este punto, resalta el potencial dado para subvertir a las imágenes poderosamente 
activas del cuerpo femenino frente a la lógica de exclusión descrita y denunciada por Cixous (1995):

El amor es un asunto de umbral. Para nosotros, hombres, que estamos hechos para triunfar, para ascender en la escala social, la tentación es buena porque nos incita, nos empuja, alimenta nuestras ambiciones. Pero la realización es peligrosa. El deseo no debe desaparecer. Para nosotros, vosotras, las mujeres, presentáis la eterna amenaza, la anticultura. No nos quedamos en vuestras casas, nos vamos a reposar a vuestras camas. Rondamos. Seducidnos, enervadnos, es todo lo que os pedimos. No hagáis de nosotros unos seres blandos, aletargados, femeninos, sin preocupaciones de tiempo ni de dinero. Para nosotros, el amor a vuestro modo es la muerte (p. 19).

En las líneas transcritas, se nota una configuración del espacio, la sujeción de los cuerpos y los afectos a dos órdenes opuestos: femenino- masculino. También, se percibe que los "peligros" vislumbrados por las formas de amor "femenina" tienen en su núcleo la verdad del estatus relacional con los Otros (seres humanos, objetos, seres fantásticos, imaginarios) del que no pueden caer presos los hombres, pues corren el riesgo de desmembrarse, mutar, someterse a una temporalidad y una espacialidad configurada desde la intimidad de lo particular, de la casa, donde el amor no dicta leyes, sino que conjura los deseos del alma y de la carne.

En "Aquel caballito de mar" se asiste a la presencia íntima de los sentidos agudizados de una madre: ojos, olfato que se quedan sin realización e impactan en el cuerpo. Se entrelazan imágenes en las que el vientre materno, escenario acuoso como el mar, comparten la potencia de acoger criaturas que esperan emerger al llegar a la orilla, tanto en la playa como al mundo, a través del alumbramiento. Según se percibe aquí: "Ella lloró a su hijo / Que todavía no olía a talco// Aquel caballito de mar/ Recostado en el mar/ Sin alcanzar la orilla" (Torres, 1982, p. 15).

En otros versos reaparece la soledad y la música que resuenan en el cuerpo, a modo de vibración externa que parece alentar al instrumento que es el cuerpo: "Ella sobrellevó / la soledad / con música// música liviana/ corriendo el tosco mueble de su cuerpo/ que siempre escondió un piano" (Torres, 1982, p. 15). Luego, se suma la metáfora de la vida como un espectáculo teatral que transcurre en un afuera (el escenario) y un adentro (el camerino) y en 
cada uno se despliega el anhelo del contacto, de la creación, del amor, de la espera, el tejido de los sueños de las mujeres, conforme se ilustra en las siguientes palabras:

Ella volvía/ al camerino, se quitaba el collar ante el espejo, // los colores de la memoria/ formando vaho ante el espejo:// estoy tan muerta, amor / y sin embargo aquí me palpo toda, / muda y sola. // Que torre. Qué mansarda. / Qué trenza. / Qué escalera sin usar que nadie trepó nunca. // Ella quedó / en el camerino del exilio/ arrumando en el piso/ una tras otra/ madejas sin usar:// ovillos de luz para tejer al hombre de sus sueños (Torres, 1982, p. 17).

En el poema "Nunca", el ojo y el poema se transforman en símbolo que entraña potencialidades misteriosas, como se observa en estos versos: "Logia secreta, el poema// ese tercer ojo// que a veces también se encharca// pero nunca deja ver/ nunca se cierra" (Torres, 1982 , p. 21). Con ello, la visión física se despliega en aptitud profética por cuanto es trascendente. Análogamente, el ojo, órgano del sentido de la visión, privilegiado por la tradición occidental como signo solar, el conocimiento, la omnipotencia que todo lo ve y sobre todo gobierna, adquiere un cariz misterioso, aunque no hermético, sino dado a todos.

El poema "La loca reina de corazones" contiene una imagen del abrazo acogedor, tibio desde la experiencia táctil de una mujer "Me abrazo a ti/ y mis senos se te recuestan encima / como dos bolsitas de agua caliente / ladeadas contra tu espalda" (Torres, 1982, p. 22). Esa calidez se interrumpe por la conciencia desgarradora de la finitud superada gracias al sueño, pues: "Despierto envuelta en mi propio grito, es mi propia muerte/ la que me talla y despierta. // Aún así, / vuelvo a soñarte vida, una y mil veces" (Torres, 1982, p. 23). La calidez de los pechos, comparados con bolsitas de té configuran, una imagen de consuelo, tibieza, seguridad, propia del hogar donde ocurre lo íntimo, lo entrañable.

Una vez avanza la lectura, en "Parche de fresco", el paisaje veraniego alcanza su punto más álgido, un meridiano trazado en el cuerpo de una mujer, quien emplea el contacto de su lengua para escribir en un idioma sutil, incluso, desconocido por el común de los seres humanos. Según se aprecia en esta sugestiva imagen: “A la hora quieta de la sombra/ trajiste arena caliente/ para regar /en medio de mi centro // y yo escribí / sobre tu pecho/ con la lengua al revés/ en el idioma de los vientos" (Torres, 1982, p. 27). Junto a esta visión se encuentra la alusión al encuentro íntimo entre dos seres: "dulzura de la piel / en las paredes/ del sudor y el recuerdo" (Torres, 1982, p. 28). Aquí confluyen elementos corporales como la lengua que 
escribe y el sudor con la arena, el viento, las paredes y el clima, lo cual da paso a un universo interconectado en el cual el ser humano ha sido incorporado en ausencia de jerarquías.

En "La ruta", la razón se increpa y se conjura en nombre del amor, tal como se nota en los versos: “A ti, razón secreta de hoy, / Navaja sin hoja de esta herida, Te hablo en nombre del amor, desde el fondo del amor/ Donde todos somos lo mismo" (Torres, 1982, p. 30). Posteriormente, el símbolo del agua y el mar es figura del deseo, puesto que en cada verso se dibuja la ola y se presencia el dolor del deseo truncado:

curvas son las olas / golpeando día tras noche/ con el suave golpe del deseo, / las olas del deseo tumbado sobre el pecho. // Este dolor de bujía luminosa ese fijo, / este grillo de la soledad que no sucumbe, esta mano que apretó tu mano no se aquieta porque estés// en otro sitio (Torres, 1982, p. 30).

Al transcurrir de imágenes y asociaciones, el poema "Un dirigible rodado y lento" se percibe como una confesión a manera de manifiesto, en el cual un genio y una figura femenina alteran con su ruido a una ciudad muda que podría resonar al figurarse como botellas. Como se aprecia a continuación: “Confieso/a quien pueda interesar//a quien creyera creerse afectado/ en una o varias de sus partes// que hice el amor / con un genio. // Mi genio y yo // habitantes ruidosos /de esta muda desnuda ciudad de botellas" (Torres, 1982, p. 32). Conforme se había apreciado en el poema "Parche fresco", las estaciones y el cuerpo femenino se despliegan de modo particular en el encuentro amoroso; aquí, el escenario es la ciudad y el tiempo se circunscribe a la noche.

En "Donde la lluvia", el acto de creación de un poema, empleando las palabras, se torna físico y doloroso, al tiempo en que se percibe una metamorfosis que involucra una suerte de sacrificio de carne y sangre en favor de la belleza:

Cada poema/ un patito feo/ que quizás muera a picotazos;/ que quizás aprenda / a nadar, hacerse cisne, // hermosearse. // Y de pronto descubro/ que el corazón lo llevo en la garganta / y me aprieta// y hay palomas de sangre en mis cuadernos (Torres, 1982, p. 41).

La imagen que predomina en estos versos es la del poema como un ave; claro está, aquí se trata de un ave que muta de pato a cisne, a paloma. Ahora, como bien se señaló en la segunda sección de esta reflexión, Chantal Maillard también recurre a la visión de un pájaro para exponer el modo en que se puede aprender del poema al leerlo, solo que en esta ocasión el pájaro está 
sobre un árbol en el que bebe agua, donde el árbol indica la cercanía con la poesía, representada con el agua.

De lo anterior, se puede afirmar que el pájaro resulta un indicador sobre la conexión entre escribir-leer-pensar-crear orgánicamente, quizá de forma particular, si se admite la propuesta de la escritura en clave femenina adelantada por Cixous (1995), para quien:

La escritura es, en mí, el paso, entrada, salida, estancia del otro que soy y no soy, que no sé ser, pero que siento pasar, que me hace vivir — que me destroza, me inquieta, me altera, ¿quién?-, ¿una, uno, unas?, varios, del desconocido que me despierta precisamente las ganas de conocer a partir de las que toda vida se eleva. Tal poblamiento no permite descanso ni seguridad, enrarece siempre la relación con lo $<<$ real $>>$, produce efectos de incertidumbre que obstaculizan la socialización del sujeto. Es angustiante, consume; y, para los hombres esta permeabilidad, esta no-exclusión, es la amenaza, lo intolerable (p. 46).

En la visión acerca de la escritura, persiste la cualidad mutable de la escritura en clave femenina, por cuanto se accede a una forma alternativa de relacionarse con lo otro: sin posesión; por el contrario, la experiencia de escritura descrita por la pensadora francesa, nacida en Argelia, comporta una experiencia radical, que lleva al límite los bastiones de la lógica enmarcada en el principio de individuación, del tercero excluso, de la angustia, la permeabilidad y la amenaza a lo seguro.

Al volver a los versos de Anabel, en el poema "Un aro jubiloso", la expresión del cuerpo se hace sutil y etérea, pero que encuentra en el recurso al objeto cotidiano, el jabón, una forma de recrear el amor mítico entre Adonis y el estanque, en el que el estanque puede dedicarle tiernas palabras de amor al amado. Como se ve en las siguientes palabras: "Yo quisiera / rodearte/ con mis brazos de grito, / mirarte una vez más /en el estanque límpido/donde aún lavo el rostro con el jabón de tu ternura" (Torres, 1982, p. 43). El agua se transfigura, es capaz de adoptar una forma corpórea con brazos, voz, ojos. Con esta imagen se trastocan los estados de la materia en favor de la creación de cierta corporalidad que sirva para el encuentro amoroso y subvierta la pasividad de la superficie reflejante de aquel estanque mítico en el que tanto amado y amante aparecían. 
Ahora, en "La emboscada", hay un retorno a la dimensión tangible del amor en la dualidad gozo-dolor. Aquí, la herida de amor se manifiesta en ampollas, heridas, punciones ocasionadas a un cuerpo que yace junto a una ventana, lugar para la espera y la esperanza. Según se aprecia en las palabras recuperadas: "Las heridas del amor, / heridas gozosas que abren una ampolla en el paladar/ o en la lengua;// heridas cubriendo el cuerpo/ tumbado junto a la ventana/ de una indolora lluvia de astillas..." (Torres, 1982, p. 44). También, en esta experiencia amorosa se incluyen tropiezos, pugnas, emboscadas en los que el cuerpo padece los rigores de la guerra, donde el amor es el altar del sacrificio, tal como se nota aquí: “Tropiezos de amor/ donde la lucha cesa/ y el amor se convierte en / la emboscada:// altas piedras del amor/ donde el cuerpo quedó atado, amordazado// embestido, sobrevolado de buitres, //sediento" (Torres, 1982, p. 44).

Al aproximarse al cierre del poemario, se halla el título "No nos abandones", plegaria a la poesía en la que se le implora prerrogativas sobre el cuerpo, el ánimo y el alma:

Consérvanos el humor y el pelo limpios, / los dientes sanos, / el cuerpo perfecto/ para que pueda bailar/gozar y solazarse en ti (Torres, 1982, p. $67)$.

Haz que yo oiga, pruebe, rechace/ haz que sufra, toque, / vea, /déjame amar y llorar y sobretodo, por favor, / haz que no olvide reír (Torres, 1982, p. 70).

Las concesiones intermediadas por la sutil palabra poética, en contraste, se aferran a lo profundo de la carne para pedir el favor de vivir con todos los sentidos y las experiencias cruciales, acompañadas del amor, la risa y el llanto. En estos versos la poesía se torna en potencia que, al invocarla, concede vitalidad, jovialidad al cuerpo; además, mantiene despiertos los sentidos y viva al alma.

Desde luego, al pasar por cada uno de los tópicos destacados, vale la pena resaltar la presencia de polaridades bajo las cuales aparece el cuerpo en su dimensión simbólica, física y metamórfica sujeto a los rigores de la experiencia amorosa concretada, interrumpida o maltrecha; además, es posibilidad, espacio, engranaje y plegaria en la que las cosas, la naturaleza, los seres, la magia pueden acontecer. Así, se descubre que el amor permea y acoge el todo en cuanto tiene visión profética y se cuela por los poros de la piel, vista como superficie 
propiciadora del contacto, sin el cual no podría darse el vínculo entre lo que-hay: seres humanos, objetos, emociones, pensamientos, palabras, cuerpos físicos o sutiles.

\section{A modo de cierre. La piel, un lugar para la creación poética}

Una vez se ha logrado establecer el panorama de cada uno de los ejes de reflexión proyectados, están dadas las condiciones para retomar la pregunta formulada al inicio de estas páginas y que vale la pena recordar: ¿Qué imágenes sobre la piel configuran la raíz poética de los versos contenidos en Las bocas del amor, de Anabel Torres?

En lo que atañe a las imágenes del cuerpo y la piel, presentes en los versos recuperados de Las bocas del amor, vale la pena señalar que se trata, principalmente de un cuerpo marcadamente femenino que se construye en conexión con aquello que le rodea. De modo que aparece tangible, intangible, mutando de estados. De ahí, se infiere que su composición orgánica rompe con las normas fijas dadas por la relación género-especie; humano, animal, cosa; así como se advierte la capacidad para subvertir las reglas relativas a los estados de la materia, junto a las posibilidades de combinación de los elementos de acuerdo a las propiedades físico-químicas bajo las cuales se había tratado de explicar los principios y funcionamiento de la naturaleza.

Al desglosar el interrogante, surge la idea de que la relación entre la experiencia de lectura, en este caso particular referida a los poemas, comporta una serie de cualidades que permiten acceder al lenguaje poético de múltiples formas y provee una sabiduría que trasciende el discurrir de la mente y el concepto. De ahí que, leer teniendo como horizonte la libertad involucra el dar cuenta de sí (cuerpo, sensibilidad, mente), así como de las maneras en que nos podemos relacionar con lo que acompaña la existencia. Esto encierra una afirmación interesante en la que el conocimiento, conectado a la carne (cuerpo), se torna vivencial, situado, relacional, múltiple, fluido; todos ellos son aspectos que permanecieron al margen del conocimiento jerárquico, lineal, basado en la abstracción de la definición que raya en lo silogístico.

El tratamiento del cuerpo y la piel destacados en este ejercicio de lectura-escritura, da lugar a una poética de la piel; pues, a partir de las potencialidades perceptivas de la superficie cutánea con sus poros, canales, terminaciones nerviosas y sus estructuras es ese territorio propicio al "intercambio" y a la posibilidad de relacionarse con el mundo. Esto nos recuerda que la piel, permeable que nos constituye es el espacio en el que todo se integra: materia, intelecto y afectos. 
Por lo tanto, en esta perspectiva, la creación estética que acude al cuerpo y a la piel, puede asumirse como lugar para la experiencia inmediata, en la cual la palabra cobra fuerza para enfrentar los límites que encuentra en el discurso y en otras expresiones. En consecuencia, es posible percatarse que al usar de modos alternativos las palabras, por ejemplo, las mujeres han conseguido, paulatinamente, vías a través de las cuales dar cabida a su experiencia de mundo sin renunciar a sus coordenadas vitales. Lo expresado anteriormente, no se agota en la potencia que se hace evidente frente a la experiencia signada como femenina; por el contrario, es un caso ejemplarizante en el que se muestra las probabilidades de configurar otros modos del decir, escribir, crear, pensar, soñar; en pocas palabras, venir a la existencia.

Desde luego, en las páginas antecedentes se construyó un escenario en que cuerpo y piel se hicieron texto para experimentar la escritura en clave femenina y de ese modo explorar otros puntos de vista para re-pensar la poética desde sus posibilidades frente al extrañamiento de mundo, así como para propiciar la apertura de los quienes buscan reivindicar su voz y sus modos de estar en el lenguaje.

\section{Referencias bibliográficas}

Abad, Héctor. (2003). La pasión de leer. Frontera seductora entre el sueño y la vigilia. Medellín: Universidad de Antioquia.

Agustoni, Prisca. (2003). Anabel Torres y su poesía untada de amor y de sangre. Aghula, revista de cultura, (34), s.p. Recuperado de http://www.jornaldepoesia.jor.br/ag34torres.htm

Borges, Jorge. (2001). Arte poética. Barcelona: Crítica.

Braidotti, Rossi. (2000). Sujetos nómades. Buenos Aires: Paidós.

Cixous, Hélène. (1995). La risa de la medusa. Ensayos sobre la escritura. Barcelona: Anthropos.

Gadamer, Hans. (1977). Verdad y método. Salamanca: Sígueme.

Larrosa, Jorge. (1996). La experiencia de la lectura. Estudios sobre literatura y formación. Barcelona: Laertes.

Larumbe, Lola. (2015). Prólogo. En Stefan Bollmann, Las mujeres y los libros. Una pasión con consecuencias (pp. 9-17). Barcelona: Planeta.

Lledó, Emilio. (1970). Filosofía y lenguaje. Barcelona: Ariel. 
Lledó, Emilio. (1992). El surco del tiempo. Meditaciones sobre el mito platónico de la escritura y la memoria. Barcelona: Crítica.

Maillard, Chantal. (2014). La baba del caracol. Cinco apuntes sobre el poema. Madrid: Vaso roto ediciones.

Mendinueta, Lauren. (2018). Encontrar a Anabel Torres. En Anabel Torres, ¿Y la alegría? (pp. 15-18). Bogotá: Letra a letra.

Moi, Toril. (2006). Teoría literaria feminista. Madrid: Cátedra.

Parra, Jaime. (2018). En un tránsito, en un tris. En Anabel Torres, ¿Y la alegría? (pp. 9-14). Bogotá: Letra a letra.

Penagos, Vilma. (2007). Buscando la escritura. En Simone Accorsi, Giobanna Buenahora, Vilma Penagos (Comps.), Buscando la escritura: una cuestión de identidad (pp. 31-57). Cali: Universidad del Valle.

Sierra, Luis. (2012). Panorama de las tres últimas décadas. Un acercamiento a las voces decantadas. En María Mercedes Carranza y Pedro Alejo Gómez Vila (Dir.), Historia de la poesía colombiana seguida de un panorama de las tres últimas décadas (pp. 719766). Bogotá: Casa de Poesía Silva.

Steiner, George. (2003). Lenguaje y silencio. Ensayos sobre la literatura, el lenguaje y lo inhumano. Barcelona: Gedisa.

Torres, Anabel. (2015). Basta de demonios interiores: ique salgan! Aurora Boreal. Recuperado de https://www.auroraboreal.net/literatura/ensayo/1998-basta-dedemonios-interiores-que-salgan

Torres, Anabel. (1982). Las bocas del amor. Bogotá: Ediciones árbol de papel. 